Czarnota Jakub, Dobrzyński Michal, Skubel Tomasz, Sokół Dorota, Dudek Iga, Drozd Malgorzata, Piecewicz-Szczęsna Halina. Phage therapy in osteoarticular infections in the era of antibiotic resistance bacteria. Journal of Education, Health and Sport. 2020;10(7):119-126. eISSN 2391-8306. DOI http://dx.doi.org/10.12775/JEHS.2020.10.07.012

https://apcz.umk.pl/czasopisma/index.php/JEHS/article/view/JEHS.2020.10.07.012

https://zenodo.org/record/3951122

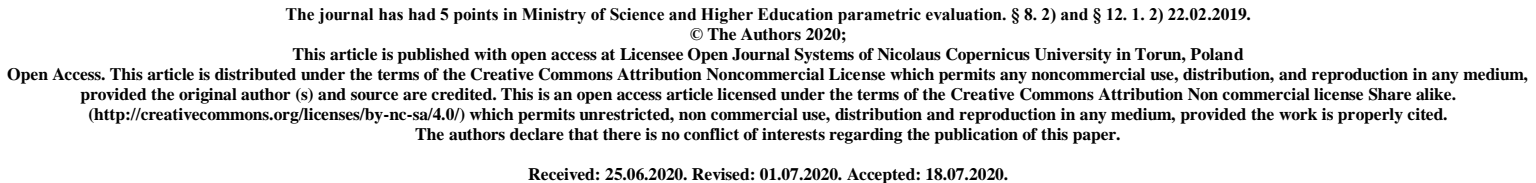

\title{
Phage therapy in osteoarticular infections in the era of antibiotic
} resistance bacteria

\author{
Jakub Czarnota ${ }^{1}$, Michał Dobrzyński ${ }^{1}$, Tomasz Skubel ${ }^{1}$, Dorota Sokól ${ }^{1}$, Iga Dudek ${ }^{1}$, \\ Małgorzata Drozd ${ }^{1}$, Halina Piecewicz-Szczęsna ${ }^{2}$ \\ ${ }^{1}$ Student Research Circle at the Department of Epidemiology and Clinical Research \\ Methodology, Medical University of Lublin \\ ${ }^{2}$ Department of Epidemiology and Clinical Research Methodology, Medical University of \\ Lublin
}

Corresponding author: Halina Piecewicz-Szczęsna, e-mail: halpiec@wp.pl ORCID ID:

Michał Dobrzyński: orcid.org/0000-0002-1416-6568; mdobrzyski4@ gmail.com

Jakub Czarnota: orcid.org/0000-0003-2783-0349; kubbaa232@interia.pl Tomasz Skubel: orcid.org/0000-0001-7572-401X; tomasz.wojciech.skubel@gmail.com Dorota Sokół: orcid.org/0000-0003-2059-7951; dorota.soko19606@gmail.com Halina Piecewicz-Szczęsna orcid.org/0000-0002-0573-7226; halpiec@wp.pl

Iga Dudek: orcid.org/0000-0002-8101-074X; iga.dudek6@ gmail.com Małgorzata Drozd: orcid.org/0000-0002-0710-2451; drozd.malg@ gmail.com 


\section{Abstract}

The increase in the incidence rate of multidrug resistant strains of bacteria has prompted scientists to look for alternatives to antibiotics. One option is phage therapy. The possibility of using phages (bacteriophages) in infections of almost every organ and system is being investigated. The treatment of osteoarticular infections using antibiotics is often very problematic, which is why this is an important area of interest for phage research.

As part of the bacteriophage experimental therapy conducted by Patey et al., 9 patients with osteoarticular diseases were treated. In 7 cases complete recovery was obtained. One patient achieved partial eradication of the pathogen with closure of several fistulas and stabilization of the general condition.

The study was carried out on an animal model by Yilmaz et al. showed greater effectiveness in eliminating MRSA colony forming units when combining bacteriophages with antibiotics (drop to 5000 units, no biofilm) than when using antibiotics alone (17,165 units survived, biofilm present). Independent application of phage therapy brought the worst effect $(30,788$ surviving units).

The results of the cited studies indicate the possible effectiveness of phage therapy in the case of osteoarticular infections. The potential synergy of antibiotics and bacteriophages in eradicating bacterial biofilm deserves attention.

Keywords: bacterial infection, antibiotic resistance, bacteriophage, antibiotic therapy, phage therapy

\section{Introduction}

In 1917, Félix d'Hérelle, observing a pan with stool cultures, noticed bacterial colony-free areas. He stated that this is due to "invisible microorganisms" that are capable of destroying bacteria. He called these microorganisms bacteriophages. Two years later, in 1919, he proved that oral administration of bacteriophages to people is safe and causes treatment of bacterial enteritis caused by Shigella sp. This event initiated a number of studies on the possibility of clinical using phage therapy. The discovery of antibiotics, their high effectiveness and availability caused that bacteriophages in Western countries have been forgotten for many years [1]. However, interest in this topic persisted in the countries of the Union of Soviet Socialist Republics (USSR), which used this method, including during World War II. In some countries, such as Poland and Georgia, this therapy has been used successfully to this day [2]. Ludwik Hirszfeld institute of immunology and experimental therapy in Wrocław is the oldest, renowned center in Central Europe, preparing phage preparations for hospital use in Poland since 1970 [1].

According to WHO, strains of antibiotic-resistant bacteria cause 700,000 deaths every year in the world. It is estimated that by 2050 this number will increase to 10 million per year. In Europe alone, antibiotic-resistant bacteria have caused 25,000. deaths in one year, which generated costs of around 1.5 billion euros (data for 2018) [3].

Bacteriophages infect a bacterial cell, leading to its lysis. In addition, they affect the host's immune system and interact with the microbiota [1], [4]. Hopes related to phage therapy are mainly associated with the treatment of chronic diseases such as complicated, chronic UTIs (bone urinary tract infections), osteomyelitis, joint prosthesis infections, respiratory tract infections, cystic fibrosis, for which the presence of multi-drug resistant bacteria (MDR-multi 
-drug resistant) is common. In the case of osteoarticular infections, bacterial biofilm and intracellular bacterial presence often occur. This is a challenge for standard antibiotic therapy. Studies proves that phage therapy can be a solution to this problem [5].

\section{Phage biology}

Phages are differentiated viruses specific for receptors on the surface of bacteria. Some of them have the ability to infect specific bacterial strains, while others have a broader specificity spectrum [6].

Bacteriophages are made of DNA or RNA encapsulated in a protein capsid. They are not able to multiply outside the host. They bind to specific receptors on the surface of a bacterial cell, introducing their genetic material inside the bacterium. Then comes the lytic or lysogenic cycle. During the lysogenic cycle, the genetic material of the phage integrates with the bacterial genome undergoing replication with it. Progeny host cells contains bacteriophage genetic material. Genetic material is not integrated in the lytic cycle. Phage takes control of bacterial replication mechanisms, progeny virions are formed, cell lysis occurs and subsequent lytic / lysogenic cycles are initiated by released virions [4], [7].

\section{Usage of bacteriophages in infections of the osteoarticular system}

In the years 2006-2018 at the Hospital Saint George in Villeneuve, France, 9 patients were treated as part of the experimental therapy (Table 1.). They suffered from osteoarticular disorders such as:

- joint prosthesis infections

- osteomyelitis

- fractures complicated by infection

In some of the cases with the infection coexisted severely healing fistulas, which were hindering treatment

The decision to implement phage therapy was made by a team consisting of: a surgeon, microbiologist and infectious diseases specialist. Samples were taken from each patient to isolate pathogens and check their sensitivity to available phage preparations. All qualified patients were previously subjected to conventional methods of treatment (surgery, antibiotic therapy), which proved to be ineffective. The most common isolated pathogen was S. aureus, a Methicillin-resistant Staphylococcus aureus several times (MRSA). Suspensions of bacteriophages were most often obtained from commercial sources. In order to optimize therapy results, phage preparations were combined with antibiotic therapy in each case.

Seven out of nine patients were completely cured. Coexisting fistulas have been closed. The improvement in bone condition was clinically and functionally verify and confirmed by imaging tests. In addition, planned limb amputations and joint prosthesis removal were avoided. In two cases full clinical success was not achieved. One patient after eradication of the primary pathogen had secondary infection with Enterococcus sp. In the second case, closure of several fistulas with stabilization of the patient's condition was achieved, however, at the site of infection, pathogens were still present. No adverse effects were observed after local application of phage preparations.

After therapy, patients were observed for many years, during which no relapses were observed. Therefore, it was assumed that 7 patients were completely cured [1]. 
Table 1. Characteristics of patients treated in the Hospital Saint George in Villeneuve, France. Source: [1]

\begin{tabular}{|c|c|c|c|c|c|}
\hline NO. & $\begin{array}{c}\text { age; } \\
\text { sex }\end{array}$ & $\begin{array}{c}\text { Onset of } \\
\text { symptoms; } \\
\text { Beginning of } \\
\text { phage therapy }\end{array}$ & Clinical condition & Bacteria & The final result \\
\hline 1 & $\begin{array}{l}44 \\
\mathrm{M}\end{array}$ & $2005 ; 2008$ & $\begin{array}{l}\text { Accidental fall; } \\
\text { multiple } \\
\text { fractures; } \\
\text { considered } \\
\text { amputation }\end{array}$ & S.aureus & $\begin{array}{c}\text { Wound closure } \\
\text { and complete recovery in } \\
2009\end{array}$ \\
\hline 2 & $\begin{array}{l}25 \\
\mathrm{M}\end{array}$ & $2007 ; 2008$ & $\begin{array}{l}\text { Car accident, } \\
\text { numerous } \\
\text { injuries; } \\
\text { uncontrolled } \\
\text { pelvic bone } \\
\text { infection }\end{array}$ & $\begin{array}{l}\text { S.Aureus; } \\
\text { P. } \\
\text { aeruginosa }\end{array}$ & Complete cure in 2010 \\
\hline 3 & $40 ; \mathrm{F}$ & $1995 ; 2009$ & $\begin{array}{l}\text { Fall leading to a } \\
\text { complex fracture } \\
\text { of the right foot; } \\
\text { planned } \\
\text { amputation }\end{array}$ & S.aureus & $\begin{array}{c}\text { Wound closure and } \\
\text { complete healing in } 2009\end{array}$ \\
\hline 4 & $80 ; \mathrm{F}$ & $2008 ; 2010$ & $\begin{array}{l}\text { Knee prosthesis } \\
\text { infection not } \\
\text { suitable for } \\
\text { surgery }\end{array}$ & $\begin{array}{c}\text { P.Aeruginos } \\
\mathrm{a}\end{array}$ & $\begin{array}{l}\text { Getting rid of } \mathrm{P} \text {. } \\
\text { aeruginos in 2012; the } \\
\text { emergence of } \\
\text { enterococcus strains }\end{array}$ \\
\hline 5 & $61 ; \mathrm{F}$ & $\begin{array}{l}1995 / 2005 \\
2010\end{array}$ & $\begin{array}{l}\text { Jaw fracture; } \\
\text { osteosynthesis } \\
\text { and infection } \\
\text { complicated by } \\
\text { fistulae }\end{array}$ & $\begin{array}{l}\text { S. aureus } \\
(\mathrm{MRSA})\end{array}$ & Complete cure in 2011 \\
\hline 6 & $90 ; \mathrm{F}$ & $\begin{array}{l}2009 / 2010 \\
2010\end{array}$ & $\begin{array}{l}\text { Fracture of the } \\
\text { femur under the } \\
\text { hip prosthesis; }\end{array}$ & $\begin{array}{l}\text { S. aureus } \\
\text { (MRSA) }\end{array}$ & Complete cure in 2011 \\
\hline 7 & $72 ; \mathrm{F}$ & $2009 ; 2013$ & $\begin{array}{l}\text { Knee prosthesis } \\
\text { infection }\end{array}$ & $\begin{array}{l}\text { Staphylococ } \\
\text { cus sp. }\end{array}$ & $\begin{array}{l}\text { Partial initial getting rid } \\
\text { of the pathogen in } 2013 \\
\text { with the closure of } \\
\text { several fistulas and } \\
\text { stabilization }\end{array}$ \\
\hline 8 & $\begin{array}{c}84 \\
\mathrm{M}\end{array}$ & $\begin{array}{l}1943 / 2012 \\
2013\end{array}$ & $\begin{array}{l}\text { Osteomyelitis of } \\
\text { the left tibia; } \\
\text { fistula next to the } \\
\text { wound }\end{array}$ & $\begin{array}{l}\text { S. aureus } \\
(\mathrm{MRSA})\end{array}$ & Complete cure in 2013 \\
\hline
\end{tabular}




\begin{tabular}{|c|c|c|c|c|c|}
\hline 9 & & & & $\begin{array}{c}\text { S. aureus eradication in } \\
\text { 2016; } \text { The appearance of } \\
\text { P.aeruginosa \& } \\
\text { streptococcus } \\
\text { constellatus; Finally } \\
\text { healed without } \\
\text { recurrence }\end{array}$ \\
\hline
\end{tabular}

Experimental studies have shown the effectiveness of a combination of bacteriophages and antibiotic therapy in combating bacterial biofilm. Yilmaz et. al. conducted an experiment on a group of 96 rats. A plastic catheter with previously prepared bacterial biofilm of MRSA and Pseudomonas Aeruginosa etiology was introduced into the medullary canal. The rats were divided into 8 groups in which various methods of therapy were used (Figure 1).

The best results were achieved in groups where a combination of antibiotic therapy and phage therapy was used. In the case of methicillin-resistant Staphylococcus aureus, biofilm was eliminated, which was not achieved in the group infected with the Pseudomonas Aeruginosa. Bacteriophage monotherapy in both groups produced worse effects than the use of antibiotics alone [5].

Diagram 1. Number of bacterial colony forming units. Experimental study. [5]

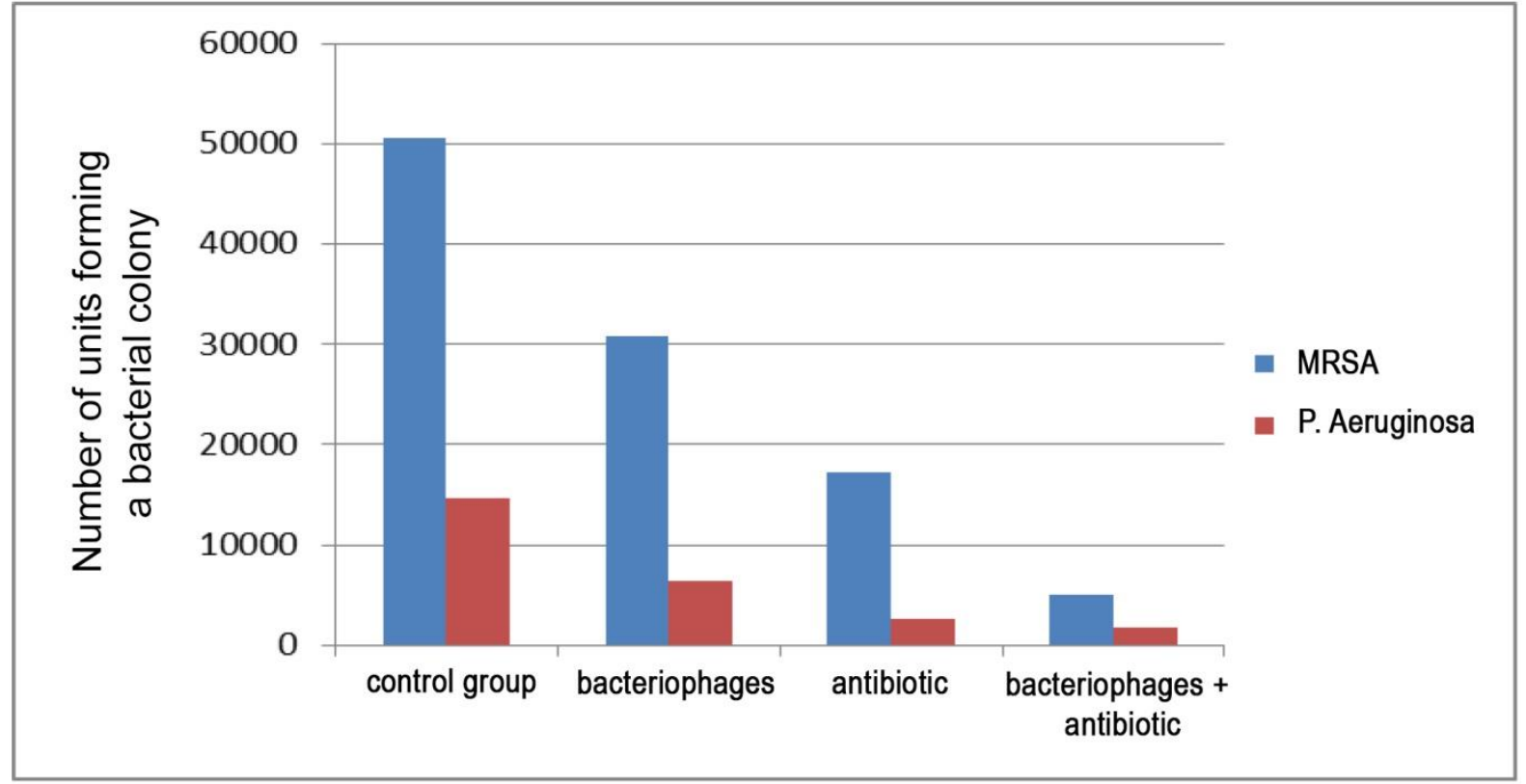

The intracellular location of bacteria can create great therapeutic difficulties in the case of osteoarticular infection. In the study of Zhang et al. the effect of phages on intracellular bacterial location was checked. The study was conducted in vitro on mammalian epithelial cells infected with Staphylococcus aureus. After 12 hours of incubation, phage therapy resulted in a significant reduction in the number of pathogens $(p<0.05)$. The results suggest that certain phage strains have the ability to cross mammalian cell membranes and destroy intracellular bacteria [8]. 


\section{Other clinical indications}

In the light of current research, phages present a number of potential clinical applications. Reports delate about the effectiveness of bacteriophages in the case of gastrointestinal infections [9], [10], local infections [11], [12], burn wound infections [13], [14], systemic infections [15], [16], urogenital infections [17], [18], nasopharyngeal infections [19], [20]

\subsection{Gastrointestinal infections}

Leszczyński et al. demonstrated the effectiveness of phage therapy in the case of persistent colonization of the gastrointestinal tract with the MRSA strain. The patient refused classical antibiotic therapy and underwent four-week bacteriophage therapy. After the end of treatment, complete eradication was found. It was confirmed by cyclic cultures. No side effects of therapy were observed [10].

Sarker et al. studied the effect of phage use on gastroenteritis. 120 pediatric patients were divided into 3 groups. The first group (placebo) received oral hydration and zinc, the second and third received various phage suspensions. No clinical differences in the course of diarrhea were observed between the groups. Causes of failure are seen, including too low E.Coli titers requiring higher doses of oral phages [9]

\subsection{Local infections}

In the case of regional infections, as in the case of the osteoarticular system infections, bacterial biofilm is often formed, which is characterized by heterogeneity and antibiotic resistance. This situation causes therapeutic difficulties [21].

In 2017, an article was published on the therapeutic options of bacteriophages in the context of a diabetic foot complicated by ulceration. It describes infections with MRSA strains resistant to standard treatments. Healing of ulcers was observed after phage therapy. In addition, methicyllin-resistant Staphylococcus aureus was eradicated [12].

\subsection{Burn wounds infections}

A multicenter, randomized, double-blind study conducted in 2015-2017 in France and Belgium analyzed the possibilities of phage therapy for treating infected burn wounds. The subjects qualified to the control group received standard treatment (silver emulsion with $1 \%$ sulfadiazine) while the research group was treated with a phage preparation applied through a bandage. The primary endpoint of the study was the median time to permanently reduce bacteria in at least two quadrants by the quadrant method, as assessed by daily microbiological testing. This goal was achieved on average in 144 hours in the phage preparation group and 47 hours in the group receiving standard treatment. The probable reason for the lower effectiveness of bacteriophages was the wrong choice of phage preparation dose in relation to the concentration of bacteria in the burn wound. It is worth noting that fewer side effects were observed in the group receiving phage therapy [13] 


\subsection{Urogenital infections}

Proteus mirabilis is a common etiological factor in urinary tract infection associated with catheterization. This is due to the bacterium's ability to colonize and create a biofilm on the surface of the catheter, which causes therapeutic difficulties.

Melo et al. studied the preventive capabilities of bacteriophages for catheter-related urinary tract infections (CAUTIs - catheter-associated urinary tract infections). The experiment was conducted on a simulation model. A significant effect of phage therapy on the reduction of bacterial biofilm formed by Proteus mirabilis has been demonstrated. This effect was positively correlated with the duration of infection. The largest difference between the control and research groups was found after 96 and 168 hours from the beginning of the experiment [18].

\subsection{Nasopharyngeal infections}

The purpose of the study by Fong et al. was an assessment of the effectiveness of phage therapy in the eradication of biofilm created by various strains of P. aeruginosa, isolated from patients with chronic sinusitis and nasal infection. The experiment was conducted in vitro. After 24 and 48 hours of study duration, a statistically significant reduction in biofilm ( $\mathrm{p}$ $<0.0001)$ was observed, regardless of the strain's antibiotic resistance. The average reduction in biomass after 48 hours was $76 \%$ of the baseline [20].

\section{Summary}

The presented research results suggest the possible effectiveness of phage therapy in osteoarticular infections and a wide spectrum of other infections. Due to the fact that this is an experimental therapy, many studies are still carried out in vitro. The promising results of clinical trials and the growing problem of antibiotic resistance suggest that phage therapy will gain great popularity in the near future. Nevertheless, until the results of extensive, randomized, multicentre studies are published, the role of phage therapy in modern medicine will remain undefined.

\section{Bibliography}

[1] O. Patey, S. McCallin, H. Mazure, M. Liddle, A. Smithyman, and A. Dublanchet, "Clinical indications and compassionate use of phage therapy: Personal experience and literature review with a focus on osteoarticular infections," Viruses, vol. 11, no. 1, Jan. 2019.

[2] D. Myelnikov, "An Alternative Cure: The Adoption and Survival of Bacteriophage Therapy in the USSR, 1922-1955," J. Hist. Med. Allied Sci., vol. 73, no. 4, p. 385, 2018.

[3] V. La Fauci and V. Alessi, "Antibiotic resistance: Where are we going?," Ann. di Ig., vol. 30, no. 4, pp. 52-57, 2018.

[4] D. M. Lin, B. Koskella, and H. C. Lin, "Phage therapy: An alternative to antibiotics in the age of multi-drug resistance," World J. Gastrointest. Pharmacol. Ther., vol. 8, no. 3, p. 162, 2017.

[5] C. Yilmaz, M. Colak, B. C. Yilmaz, G. Ersoz, M. Kutateladze, and M. Gozlugol, "Bacteriophage therapy in implant-related infections: An experimental study," J. Bone Jt. Surg. - Ser. A, vol. 95, no. 2, pp. 117-125, Jan. 2013. 
[6] B. Koskella and S. Meaden, "Understanding Bacteriophage Specificity in Natural Microbial Communities," Viruses, vol. 5, no. 3, pp. 806-823, Mar. 2013.

[7] M. G. Weinbauer, "Ecology of prokaryotic viruses," FEMS Microbiology Reviews, vol. 28, no. 2. Oxford Academic, pp. 127-181, 01-May-2004.

[8] L. Zhang et al., "Intracellular Staphylococcus aureus control by virulent bacteriophages within MAC-T bovine mammary epithelial cells," Antimicrob. Agents Chemother., vol. 61, no. 2, Feb. 2017.

[9] S. A. Sarker et al., "Oral Phage Therapy of Acute Bacterial Diarrhea With Two Coliphage Preparations: A Randomized Trial in Children From Bangladesh," EBioMedicine, vol. 4, pp. 124-137, Feb. 2016.

[10] P. Leszczyński, B. Weber-Dąbrowska, M. Kohutnicka, M. Łuczak, A. Górecki, and A. Górski, "Successful eradication of methicillin-resistant Staphylococcus aureus (MRSA) intestinal carrier status in a healthcare worker - Case report," Folia Microbiol. (Praha)., vol. 51, no. 3, pp. 236-238, May 2006.

[11] E. Jończyk-Matysiak et al., "Prospects of Phage Application in the Treatment of Acne Caused by Propionibacterium acnes," Front. Microbiol., vol. 8, p. 164, Feb. 2017.

[12] V. V. Morozova, Y. N. Kozlova, D. A. Ganichev, and N. V. Tikunova, "Bacteriophage treatment of infected diabetic foot ulcers," in Methods in Molecular Biology, vol. 1693, Humana Press Inc., 2018, pp. 151-158.

[13] P. Jault et al., "Efficacy and tolerability of a cocktail of bacteriophages to treat burn wounds infected by Pseudomonas aeruginosa (PhagoBurn): a randomised, controlled, doubleblind phase 1/2 trial," Lancet Infect. Dis., vol. 19, no. 1, pp. 35-45, Jan. 2019.

[14] T. Rose et al., "Experimental phage therapy of burn wound infection: difficult first steps.,” Int. J. Burns Trauma, vol. 4, no. 2, pp. 66-73, 2014.

[15] P. Speck and A. Smithyman, "Safety and efficacy of phage therapy via the intravenous route," FEMS Microbiol. Lett., vol. 363, no. 3, Feb. 2016.

[16] R. T. Schooley et al., "Development and use of personalized bacteriophage-based therapeutic cocktails to treat a patient with a disseminated resistant Acinetobacter baumannii infection," Antimicrob. Agents Chemother., vol. 61, no. 10, Oct. 2017.

[17] L. Leitner et al., "Bacteriophages for treating urinary tract infections in patients undergoing transurethral resection of the prostate: A randomized, placebo-controlled, doubleblind clinical trial," BMC Urol., vol. 17, no. 1, pp. 1-6, Sep. 2017.

[18] L. D. R. Melo et al., "Development of a phage cocktail to control Proteus mirabilis catheter-associated urinary tract infections," Front. Microbiol., vol. 7, no. JUN, p. 1024, 2016. [19] G. Zhang et al., "Bacteriophage effectively kills multidrug resistant Staphylococcus aureus clinical isolates from chronic rhinosinusitis patients," Int. Forum Allergy Rhinol., vol. 8, no. 3, pp. 406-414, Mar. 2018.

[20] S. A. Fong et al., "Activity of Bacteriophages in Removing Biofilms of Pseudomonas aeruginosa Isolates from Chronic Rhinosinusitis Patients," Front. Cell. Infect. Microbiol., vol. 7, no. SEP, p. 418, Sep. 2017.

[21] A. Malik, Z. Mohammad, and J. Ahmad, "The diabetic foot infections: Biofilms and antimicrobial resistance," Diabetes Metab. Syndr. Clin. Res. Rev., vol. 7, no. 2, pp. 101-107, Apr. 2013. 